\title{
Microstructure and Magnetic Properties of Highly Ordered SBA-15 Nanocomposites Modified with $\mathrm{Fe}_{2} \mathrm{O}_{3}$ and $\mathrm{Co}_{3} \mathrm{O}_{4}$ Nanoparticles
}

\author{
P. F. Wang, H. X. Jin, M. Chen, D. F. Jin, B. Hong, H. L. Ge, \\ J. Gong, X. L. Peng, H. Yang, Z. Y. Liu, and X. Q. Wang \\ Zhejiang Province Key Laboratory of Magnetism, College of Materials Science and Engineering, \\ China Jiliang University, Hangzhou 310018, China \\ Correspondence should be addressed to X. Q. Wang, wangxinqingnano@163.com
}

Received 20 June 2012; Revised 14 August 2012; Accepted 1 September 2012

Academic Editor: Alireza Khataee

Copyright (C) 2012 P. F. Wang et al. This is an open access article distributed under the Creative Commons Attribution License, which permits unrestricted use, distribution, and reproduction in any medium, provided the original work is properly cited.

\begin{abstract}
Owing to the unique order mesopores, mesoporous SBA-15 could be used as the carrier of the magnetic nanoparticles. The magnetic nanoparticles in the frame and the mesopores lead to the exchange-coupling interaction or other interactions, which could improve the magnetic properties of SBA-15 nanocomposites. Mesoporous Fe/SBA-15 had been prepared via in situ anchoring $\mathrm{Fe}_{2} \mathrm{O}_{3}$ into the frame and the micropores of SBA-15 using the sol-gel and hydrothermal processes. $\mathrm{Co}_{3} \mathrm{O}_{4}$ nanoparticles had been impregnated into the mesopores of Fe/SBA-15 to form mesoporous Fe/SBA-15- $\mathrm{Co}_{3} \mathrm{O}_{4}$ nanocomposites. XRD, HRTEM, VSM, and $\mathrm{N}_{2}$ physisorption isotherms were used to characterize the mesostructure and magnetic properties of the SBA-15 nanocomposites, and all results indicated that the $\mathrm{Fe}_{2} \mathrm{O}_{3}$ nanoparticles presented into the frame and micropores, while the $\mathrm{Co}_{3} \mathrm{O}_{4}$ nanoparticles existed inside the mesopores of Fe/SBA-15. Furthermore, the magnetic properties of SBA-15 could be conveniently adjusted by the $\mathrm{Fe}_{2} \mathrm{O}_{3}$ and $\mathrm{Co}_{3} \mathrm{O}_{4}$ magnetic nanoparticles. Fe/SBA-15 exhibited ferromagnetic properties, while the impregnation of $\mathrm{Co}_{3} \mathrm{O}_{4}$ nanoparticles greatly improved the coercivity with a value of $1424.6 \mathrm{Oe}$, which was much higher than that of Fe/SBA-15.
\end{abstract}

\section{Introduction}

SBA-15, a type of mesoporous zeolite, features large uniform mesopores arranged into a two-dimensional (2D) hexagonal structure with the micropores $(1 \sim 2 \mathrm{~nm})$ in the frame $[1,2]$. Due to its unique and regular pore structures, tunable pore sizes $(5-30 \mathrm{~nm})$, and high surface areas, SBA-15 has found many potential applications in catalysis, separation, drug targeting, and so forth [3-11]. However, the relatively inert chemical reactivity observed in SBA- 15 had significantly limited its wide practical applications. Meanwhile, chemical modification to SBA-15 was one of the approaches for reaching its full potential. After a variety of surface modifications, such as the introduction of guest molecules through coating or incorporations and surface or mesopore grafting of metal atoms, the obtained new materials were suitable for many new applications, such as catalysis, separation, and drug delivery.
A number of studies have been reported on the modification of SBA-15 with implantation of various metal atoms such as $\mathrm{Al}, \mathrm{Ti}, \mathrm{Co}$, and $\mathrm{Fe}$ [11-20]. Park et al. [9] utilized polyethylene oxide (PEO) as an encapsulating agent to disperse $\mathrm{NiO}$ onto SBA-15. Yang et al. [18] incorporated $\mathrm{Pd}$ nanoparticles in the micropores of SBA-15, where selective surface functionalization of the mesopores and micropores of SBA-15 were developed. Yiu et al. [20] synthesized novel magnetic Fe metal-silica (Fe/SBA-15) and magnetite-silica $\left(\mathrm{Fe}_{3} \mathrm{O}_{4} / \mathrm{SBA}-15\right)$ nanocomposites with high $\mathrm{Fe}$ contents through temperature programmed reduction, which exhibited superparamagnetic properties with a total magnetization value of $17 \mathrm{emu} \cdot \mathrm{g}^{-1}$.

Magnetic mesoporous silica materials were much in demand as promising carriers for drug delivery [10, 21-23]. Moreover, magnetic mesoporous materials were attractive supports for protein or enzymes immobilization [24, 25], 
with which drug effects and separation could be operated easily with a magnet. To search for mesoporous materials with the better magnetic response, a great deal of work had been done in the area. For example, Zhu et al. [10] prepared a novel magnetic and temperature-responsive drug delivery system based on poly(N-isopropylacrylamide) (PNIPAM) modified SBA-15 containing magnetic $\gamma$ - $\mathrm{Fe}_{2} \mathrm{O}_{3}$ nanoparticles. Magnetically separable Fe/SBA-15 nanocomposites were synthesized by Lin et al. through selective deposition of $\mathrm{Fe}_{2} \mathrm{O}_{3}$ nanoparticles into the micropores of SBA-15, and $\mathrm{Fe}_{2} \mathrm{O}_{3}$ nanoparticles embedded in the micropores exhibited superparamagnetic properties [22].

In our previous work, $\mathrm{Fe} / \mathrm{SBA}-15[26,27]$ and $\mathrm{CoFe}_{2} \mathrm{O}_{4}$ doped Fe/SBA-15 [28] were reported, where $\mathrm{Fe}_{2} \mathrm{O}_{3}$ nanoparticles were anchored into the frame or micropores and $\mathrm{CoFe}_{2} \mathrm{O}_{4}$ nanoparticles were confined inside the mesopores of Fe/SBA-15. Magnetic properties, including saturation magnetization intensity $(\mathrm{Ms})$ and coercivity $(\mathrm{Hc})$, were able to be controlled to a certain extent. In order to further adjustment of magnetic performance of SBA-15, especially for $\mathrm{Hc}$, we attempted to implant $\mathrm{Co}_{3} \mathrm{O}_{4}$ nanoparticles into the mesopores of Fe/SBA-15 in this paper. Herein, Fe/SBA15 was firstly prepared, and then $\mathrm{Co}_{3} \mathrm{O}_{4}$ nanoparticles were implanted into its mesopores (denoted $\mathrm{Fe} / \mathrm{SBA}-15-\mathrm{Co}_{3} \mathrm{O}_{4}$ below). The microstructure and magnetic properties of the obtained SBA-15 samples were analyzed by XRD, HRTEM, VSM, and $\mathrm{N}_{2}$ physisorption isotherms, and the results were discussed in detail.

\section{Experimental}

2.1. Synthesis. In a typical synthesis procedure, triblock copolymer $\mathrm{P} 123\left(\mathrm{EO}_{20} \mathrm{PO}_{70} \mathrm{EO}_{20}, 2.00 \mathrm{~g}\right)$ and ferric nitrate $\left(\mathrm{Fe}\left(\mathrm{NO}_{3}\right)_{3} \cdot 9 \mathrm{H}_{2} \mathrm{O}\right)$ were dissolved in $\mathrm{HCl}(2.00 \mathrm{M}, 60 \mathrm{~mL})$ before tetraethoxysilane (TEOS, $4.50 \mathrm{~mL}$ ) was added. The different amounts of ferric nitrate were added into the mixture with the Fe to $\mathrm{Si}$ molar ratios of $0,0.04,0.08$, 0.12 , and 0.16 in each separated synthesis. After stirring for $24 \mathrm{~h}$ at $313 \mathrm{~K}$, the mixture was transferred to an autoclave and hydrothermally treated for another $24 \mathrm{~h}$ at $373 \mathrm{~K}$. The obtained solid by filtration was dried at $353 \mathrm{~K}$ and calcined at $823 \mathrm{~K}$ for $6 \mathrm{~h}$ to remove the triblock copolymer and form $\mathrm{Fe}_{2} \mathrm{O}_{3}$ in the final products. The final products were denoted Fe/SBA- 15 , or specifically $x \% \mathrm{Fe} / \mathrm{SBA}-15$, where $x$ represented the molar ratio of $\mathrm{Fe}$ to $\mathrm{Si}$.

Fe/SBA-15- $\mathrm{Co}_{3} \mathrm{O}_{4}$ nanocomposites were synthesized through ethanol impregnation. Owing to the mesostructure revealed below, $8 \% \mathrm{Fe} / \mathrm{SBA}-15$ was adopted as a template to produce $\mathrm{Fe} / \mathrm{SBA}-15-\mathrm{Co}_{3} \mathrm{O}_{4}$ nanocomposites. After cobalt nitrates $\left(\mathrm{Co}\left(\mathrm{NO}_{3}\right)_{2} \cdot 6 \mathrm{H}_{2} \mathrm{O}: 0.001,0.005,0.01\right.$, and $0.02 \mathrm{~mol}$ each) were dissolved in ethanol $(25 \mathrm{~mL}), 8 \% \mathrm{Fe} / \mathrm{SBA}-15$ $(1.00 \mathrm{~g})$ were added. All mixtures were kept stirring at room temperature until ethanol was completely volatilized. After dried at $318 \mathrm{~K}$ for $24 \mathrm{~h}$, all samples were calcined at $823 \mathrm{~K}$ for $6 \mathrm{~h}$ with a ramp of $2^{\circ} \mathrm{C} \cdot \mathrm{min}^{-1}$. The $\mathrm{Co}_{3} \mathrm{O}_{4}$ doped samples were denoted $\mathrm{Fe} / \mathrm{SBA}-15-\mathrm{Co}-y$, where $y$ represented the mole of $\mathrm{Co}\left(\mathrm{NO}_{3}\right)_{2} \cdot 6 \mathrm{H}_{2} \mathrm{O}$ in $25 \mathrm{~mL}$ of ethanol.
2.2. Characterizations. X-Ray powder diffraction (XRD: XD$5 \mathrm{~A}$, wavelength $0.154 \mathrm{~nm}$ ) was recorded on an X-ray diffractometer equipped with a $\mathrm{Cu}$ target in a $2 \theta$ range between $15^{\circ}$ and $80^{\circ}$ with a scanning rate of $0.02^{\circ} /$ step. High resolution transmission electron microscopy (HRTEM: JEM-1200EX) was used for analyzing the microstructure of all samples. The specimens for HRTEM were well dispersed in dehydrated ethanol by ultrasound and dropped on $\mathrm{Cu}$ grids. Nitrogen physisorption experiments were carried out at $77 \mathrm{~K}$ on a Micromeritics ASAP 2020 surface area and porosity analyzer. All samples were outgassed at $200^{\circ} \mathrm{C}$ in the port of the adsorption analyzer for $4 \mathrm{~h}$ before nitrogen physisorption. Specific surface areas were calculated via the BrunauerEmmett-Teller (BET) model, and pore size distribution curves were obtained from the adsorption branch using the Barrett-Joyner-Halenda (BJH) method. The magnetic properties of the as-prepared SBA- 15 nanocomposites were measured up to $2 \mathrm{~T}$ at room temperature on a Vibrating Sample Magnetometer (VSM: 7407 Model) from Lake Shore Cryotronics, Inc., USA. From the obtained hysteresis loops, Ms and $\mathrm{Hc}$ were determined.

\section{Results and Discussion}

Figure 1 presented the XRD patterns of a series of all Fe/SBA15 samples with all peaks normalized according the strongest peak in each curve. A very wide diffraction peak was found at $20-30^{\circ}$ in all patterns that was attributed to amorphous silica. When $x \leq 4$, only a broad peak of silica was observed and the peaks of $\alpha-\mathrm{Fe}_{2} \mathrm{O}_{3}$ were undetected at a high scanning angle, indicating that $\alpha-\mathrm{Fe}_{2} \mathrm{O}_{3}$ nanoparticles were well dispersed in SBA-15. As $x \geq 8, \alpha-\mathrm{Fe}_{2} \mathrm{O}_{3}$ nanoparticles with phase structure R-3c(167) were detected. Based on the previous work with small-angle XRD [26] and $\mathrm{N}_{2}$ adsorption-desorption isotherms below, $\alpha-\mathrm{Fe}_{2} \mathrm{O}_{3}$ nanoparticles should exist in the frame of SBA-15. The intensity ratio of the hematite $\alpha-\mathrm{Fe}_{2} \mathrm{O}_{3}$ peak to the silica peak increased with $\mathrm{x}$. Such change was attributed to the better crystallization of $\alpha$ $\mathrm{Fe}_{2} \mathrm{O}_{3}$ for the larger grain size, which could be easily detected by XRD.

The $\mathrm{N}_{2}$ adsorption-desorption isotherms (Figure 2(a)) and pore size distribution curves (Figure 2(b)) of all as-prepared Fe/SBA-15 samples were given in Figure 2, and Table 1 summarizes the data of the surface area, pore volume, and pore size of pure SBA-15 and Fe/SBA-15. Clearly, the $\mathrm{N}_{2}$ physisorption isotherms of all Fe/SBA-15 belonged to type IV classification with a type $\mathrm{H} 1$ hysteresis loop at high relative pressure, indicating that as-prepared Fe/SBA-15 still possessed a well-defined hexagonal pore structure same as the pure SBA-15. Furthermore, the pronounced capillary condensation step observed for all Fe/SBA-15 samples showed no significant change compared to pure SBA- 15 . Coupled with the pore volume results in Table $1, \alpha-\mathrm{Fe}_{2} \mathrm{O}_{3}$ doping had a little effect on the pore volume of SBA-15, and all samples showed a narrow pore size distribution. The most probable pore size of all Fe/SBA-15 samples in Figure 2(b) was always larger than the average pore size, which indicated that a considerable portion of micropores existed in the 


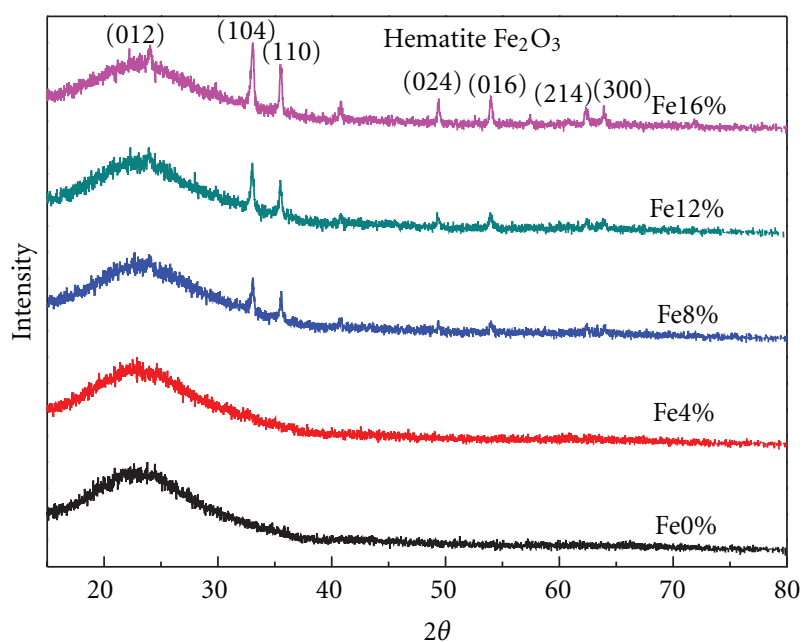

FIGURE 1: XRD patterns of all Fe/SBA-15 samples.

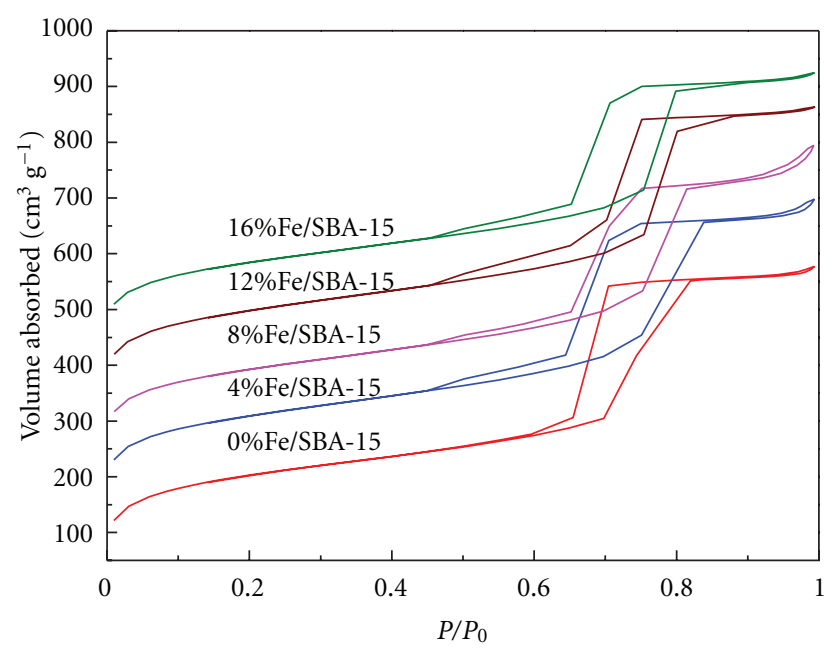

(a)

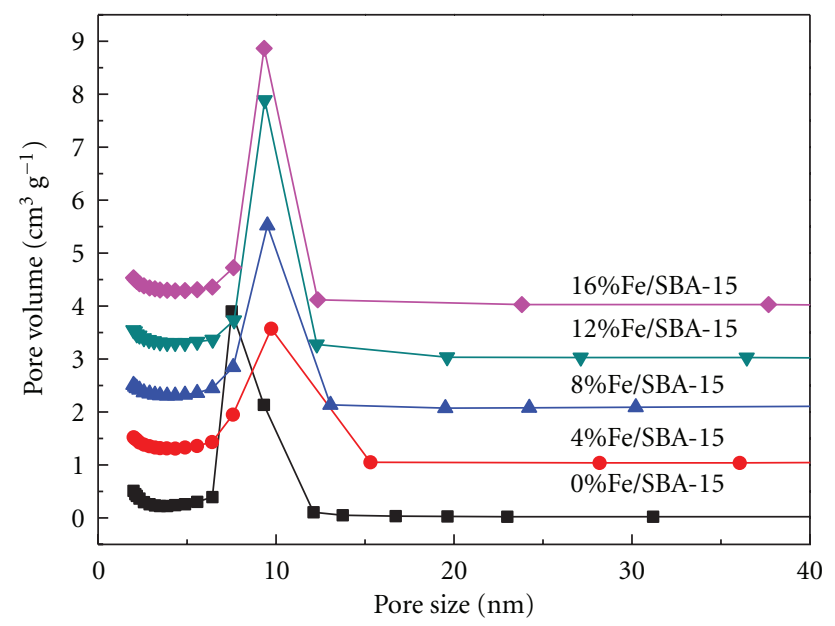

(b)

FIGURE 2: $\mathrm{N}_{2}$ physisorption isotherms (a) and pore size distribution (b) of mesoporous Fe/SBA-15.
TABLE 1: Structure parameters of all Fe/SBA-15 samples.

\begin{tabular}{lccc}
\hline Samples & $S_{\text {BET }}\left(\mathrm{m}^{2} \mathrm{~g}^{-1}\right)$ & $V\left(\mathrm{~cm}^{3} \mathrm{~g}^{-1}\right)$ & Pore diameter $(\mathrm{nm})$ \\
\hline Pure SBA-15 & 719 & 0.87 & 6.6 \\
$4 \%$ Fe/SBA-15 & 740 & 0.89 & 6.8 \\
$8 \%$ Fe/SBA-15 & 684 & 0.86 & 7.0 \\
$12 \%$ Fe/SBA-15 & 704 & 0.86 & 6.5 \\
$16 \%$ Fe/SBA-15 & 658 & 0.80 & 6.4 \\
\hline
\end{tabular}

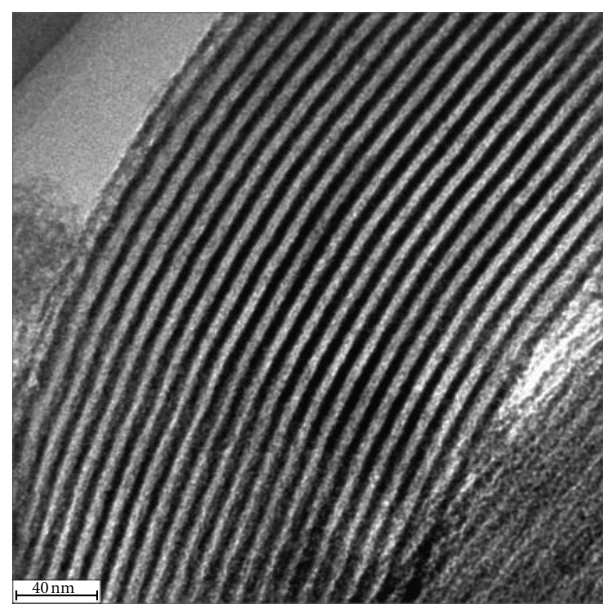

FIGURE 3: HRTEM image of as-prepared mesoporous $8 \% \mathrm{Fe} / \mathrm{SBA}-15$ $(40 \mathrm{~nm})$.

frame of SBA-15. When Fe atoms in situ replacing Si were rooted in the SBA- 15 frame and form $\alpha-\mathrm{Fe}_{2} \mathrm{O}_{3}$, part of $\alpha$ $\mathrm{Fe}_{2} \mathrm{O}_{3}$ entered the micropores. As a result, the micropores were filled and the average pore size of Fe/SBA-15 increased. Particularly, the most probable pore size of Fe/SBA-15 was larger than that of SBA-15, suggesting the partial addition of $\alpha-\mathrm{Fe}_{2} \mathrm{O}_{3}$ came into the micropores. Given the results in Figure 2(b) and Table 1, it could be concluded that no $\alpha-\mathrm{Fe}_{2} \mathrm{O}_{3}$ presented in the mesopores of SBA- 15 when $x<8$, which accorded with previous studies [26]. With an increasing $x$, the average pore size of Fe/SBA- 15 increased to a maximum of $7 \mathrm{~nm}$ at $x=8$. When $x>8$, partial $\alpha-\mathrm{Fe}_{2} \mathrm{O}_{3}$ nanoparticles came into the mesopores of Fe/SBA-15 and thus the average pore size decreased. As it could be seen from Table 1 that the surface area decreased, it was likely because the mesopores of Fe/SBA-15 were partially blocked.

The above results indicated that all as-prepared Fe/SBA15 still possessed a well-defined 2D hexagonal pore structure, which was confirmed by HRTEM image of $8 \% \mathrm{Fe} / \mathrm{SBA}-15$ in Figure 3. Ordered channels in the structure were clearly observed along the [110] zone axis (perpendicular to the mesopores of SBA-15), suggesting that $\alpha-\mathrm{Fe}_{2} \mathrm{O}_{3}$ nanoparticles caused no damage to the mesostructure of SBA-15. The mesopore diameter in Figure 3 was measured at about $8 \mathrm{~nm}$, similar to the pore size determined by the $\mathrm{N}_{2}$ physisorption isotherms. Just like the above analysis, $\alpha-\mathrm{Fe}_{2} \mathrm{O}_{3}$ nanoparticles were present in the frame or micropores of Fe/SBA-15 when $x<8$. 


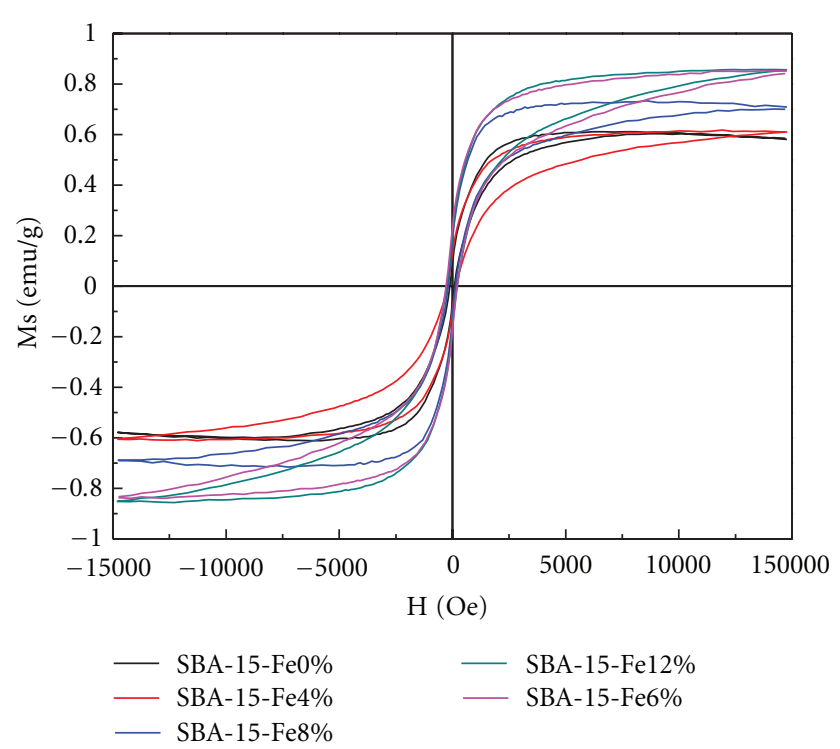

Figure 4: Hysteresis loops of all as-prepared mesoporous Fe/SBA15.

Furthermore, the magnetic properties of as-prepared Fe/SBA-15 were characterized by VSM with results shown in Figure 4. Apparently, the addition of $\alpha-\mathrm{Fe}_{2} \mathrm{O}_{3}$ nanoparticles improved the magnetic properties and all Fe/SBA-15 samples exhibited ferromagnetic properties. Hc of Fe/SBA-15 was approximately $244.4 \mathrm{Oe}$, which was much larger than that of pure $\alpha-\mathrm{Fe}_{2} \mathrm{O}_{3}(1.0 \mathrm{Oe})$. Normally for magnetic nanoparticles, Hc was related to the diameter of the magnetic singledomain size and supermagnetism critical size. When the diameter was larger than the supermagnetism critical size while smaller than the single-domain size, Hc increased with an increasing size of nanoparticles. Such rule also governed the $\alpha-\mathrm{Fe}_{2} \mathrm{O}_{3}$ nanoparticles in Fe/SBA-15. Hence, Hc of the Fe/SBA- 15 samples increased with higher loading of $\alpha-\mathrm{Fe}_{2} \mathrm{O}_{3}$ nanoparticles. Since $\alpha-\mathrm{Fe}_{2} \mathrm{O}_{3}$ were spin antiferromagnetic material, Ms of Fe/SBA-15 was very low, Ms strengthened from $0.6 \mathrm{emu} \cdot \mathrm{g}^{-1}$ to $0.85 \mathrm{emu} \cdot \mathrm{g}^{-1}$ with an increasing $x$ from 4 to 16 .

As shown in Table 1, the average pore size of $8 \% \mathrm{Fe} / \mathrm{SBA}$ 15 was the largest at about $7.0 \mathrm{~nm}$, so $8 \% \mathrm{Fe} / \mathrm{SBA}-15$ was chosen as a hard template to synthesize $\mathrm{Fe} / \mathrm{SBA}-15-\mathrm{Co}_{3} \mathrm{O}_{4}$ nanocomposites. As seen from normalized XRD patterns in Figure $5, \mathrm{Co}_{3} \mathrm{O}_{4}$ nanoparticles were successfully implanted into $8 \% \mathrm{Fe} / \mathrm{SBA}-15$, and the diffraction peak intensity of spine phase $\mathrm{Co}_{3} \mathrm{O}_{4}$ became larger with an increasing $y$. The widened peak of amorphous silica observed at $20-30^{\circ}$ becomes weak and almost disappears when $y \geq 0.01$, which indicates that $\mathrm{Co}_{3} \mathrm{O}_{4}$ nanoparticles became more crystalline with an increasing $y$.

Figure 6 presented the $\mathrm{N}_{2}$ adsorption-desorption isotherms (Figure 6(a)) and pore size distribution curves (Figure $6(\mathrm{~b})$ ) of $8 \% \mathrm{Fe} / \mathrm{SBA}-15-\mathrm{Co}_{3} \mathrm{O}_{4}$, while Table 2 summarized their structural parameters. Typical type $\mathrm{H} 1$ hysteresis loops were observed for all isotherms in Figure 6(a), indicating a well-defined mesostructure in the hard template

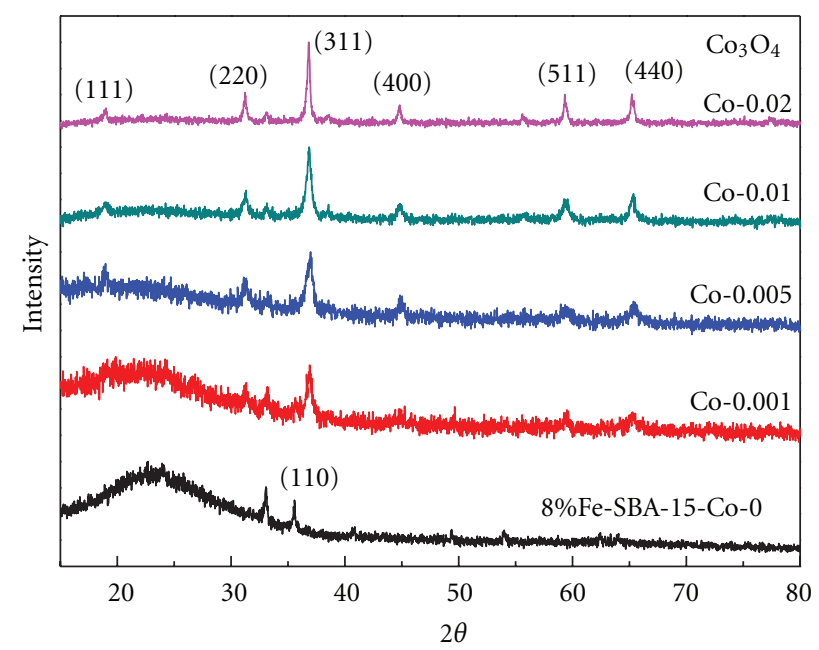

FIGURE 5: XRD patterns of Fe/SBA-15- $\mathrm{Co}_{3} \mathrm{O}_{4}$ nanocomposites.

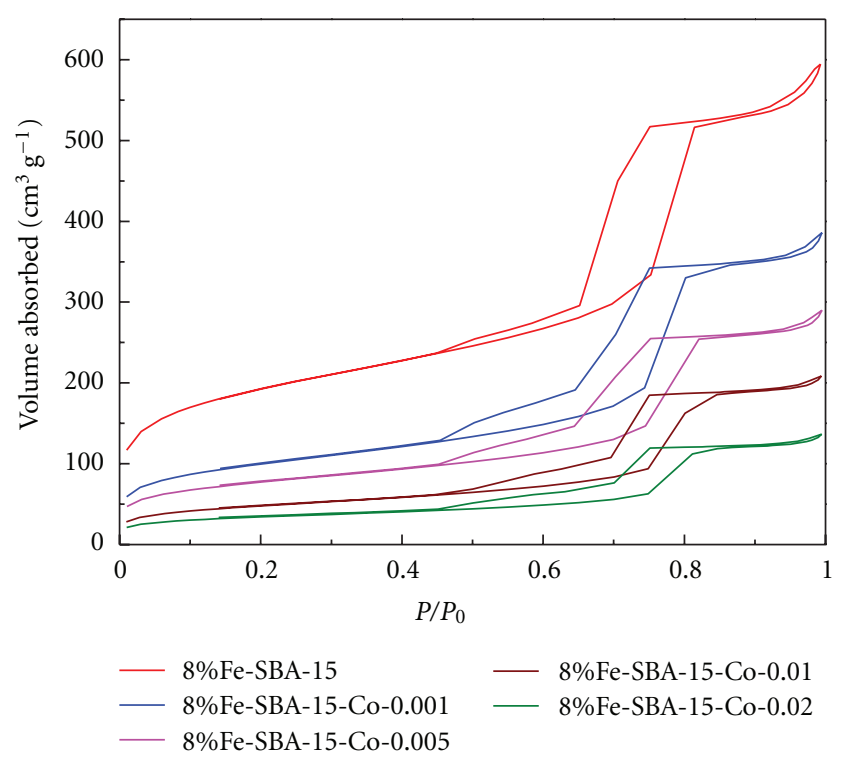

(a)

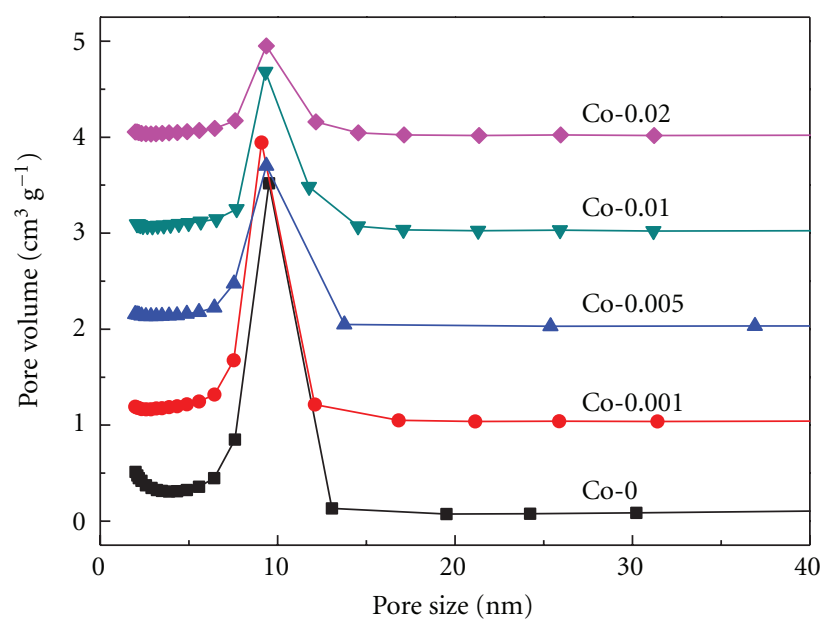

(b)

FIGURE 6: $\mathrm{N}_{2}$ physisorption isotherms (a) and pore size distribution (b) of $\mathrm{Fe} / \mathrm{SBA}-15-\mathrm{Co}_{3} \mathrm{O}_{4}$ nanocomposites. 
TABLE 2: Structure parameters of Fe/SBA-15- $\mathrm{Co}_{3} \mathrm{O}_{4}$ nanocomposites.

\begin{tabular}{lccc}
\hline Samples (Co: $\mathrm{mol})$ & $S_{\text {BET }}\left(\mathrm{m}^{2} \mathrm{~g}^{-1}\right)$ & $V\left(\mathrm{~cm}^{3} \mathrm{~g}^{-1}\right)$ & $\begin{array}{c}\text { Pore } \\
\text { diameter }(\mathrm{nm})\end{array}$ \\
\hline 8\%Fe/SBA-15 & 684 & 0.86 & 7.0 \\
8\%Fe/SBA-15-Co-0.001 & 356 & 0.56 & 7.6 \\
8\%Fe/SBA-15-Co-0.005 & 275 & 0.42 & 7.6 \\
8\%Fe/SBA-15-Co-0.01 & 171 & 0.30 & 8.3 \\
8\%Fe/SBA-15-Co-0.02 & 121 & 0.19 & 8.5 \\
\hline
\end{tabular}

$8 \% \mathrm{Fe} / \mathrm{SBA}-15$. However, the loop became shorter with an increasing $y$. The relative pressure in the hysteresis loop for each sample was also enhanced with an increasing $y$, likely due to the increase in the pore dimensions. This conclusion was confirmed below by the average pore size summarized in Table 2. It was understood that small pores were easily blocked by $\mathrm{Co}_{3} \mathrm{O}_{4}$ nanoparticles, which led to an increase in the average pore diameter. The pore volume of $8 \% \mathrm{Fe} / \mathrm{SBA}-15-\mathrm{Co}_{3} \mathrm{O}_{4}$ decreased greatly with an increasing $y$ down to $0.19 \mathrm{~cm}^{3} \mathrm{~g}^{-1}$ for $8 \% \mathrm{Fe} / \mathrm{SBA}-15-\mathrm{Co}-0.02$, which was only about one fifth of $0.86 \mathrm{~cm}^{3} \mathrm{~g}^{-1}$ for Fe/SBA-15 and one third of $0.56 \mathrm{~cm}^{3} \mathrm{~g}^{-1}$ for Fe/SBA-15-Co-0.001. The most probable pore size in Figure 6(b) was similar to that of the template of $8 \% \mathrm{Fe} / \mathrm{SBA}-15$, revealing only partial mesopores were blocked by the $\mathrm{Co}_{3} \mathrm{O}_{4}$ nanoparticles. In summary, $\mathrm{Co}_{3} \mathrm{O}_{4}$ nanoparticles partially occupied the mesopores of Fe/SBA-15, which resulted in the decrease of surface area and pore volume [29-31].

An HRTEM image of $8 \% \mathrm{Fe} / \mathrm{SBA}-15-\mathrm{Co}-0.02$ was shown in Figure 7, where ordered mesopores were observed clearly along the [110] zone axis. Consistent with the $\mathrm{N}_{2}$ adsorptiondesorption isotherms in Figure 6(a), Fe/SBA-15-Co-0.02 still retained the same ordered $2 \mathrm{D}$ hexagonal $\mathrm{p} 6 \mathrm{~mm}$ structure as pure SBA-15. The mesochannel structure of the hard template was also observed after the introduction of $\mathrm{Co}_{3} \mathrm{O}_{4}$. It could also be seen that $8 \% \mathrm{Fe} / \mathrm{SBA}-15-\mathrm{Co}-0.02$ actually had the ordered mesopores with a diameter of about $8 \mathrm{~nm}$. Moreover, it was clear in Figure 7(a) that a part of mesopores were free of $\mathrm{Co}_{3} \mathrm{O}_{4}$ nanoparticles, agreeing well with the volume change in Table 2 . On the other hand, $\mathrm{Co}_{3} \mathrm{O}_{4}$ nanowires were observed in Figure 7(b) after SBA-15 was removed with a hot $\mathrm{NaOH}$ solution $(2.0 \mathrm{M})$. Thus, the $\mathrm{Co}_{3} \mathrm{O}_{4}$ nanoparticles are successfully implanted into the mesopores of Fe/SBA-15.

Finally, the magnetic properties of $8 \% \mathrm{Fe} / \mathrm{SBA}-15-\mathrm{Co}_{3} \mathrm{O}_{4}$ were measured and discussed by VSM with results summarized in Figure 8. As shown, both $\mathrm{Hc}$ and Ms of Fe/SBA-15$\mathrm{Co}_{3} \mathrm{O}_{4}$ were greatly affected by the introduction of $\mathrm{Co}_{3} \mathrm{O}_{4}$ nanoparticles. The $\mathrm{Co}_{3} \mathrm{O}_{4}$ nanoparticles belonged to the spine phase structure consisting of $\mathrm{Co}^{2+}\left[\mathrm{Co}^{3+}\right]_{2} \mathrm{O}_{4}$. Since $\mathrm{Co}^{2+}$ had a large magnetic anisotropy, it gave a higher $\mathrm{Hc}$ to the $\mathrm{Co}_{3} \mathrm{O}_{4}$ materials. Hc increased with an increasing $y$ before reaching 0.02 with the maximum value of $1424.6 \mathrm{Oe}$, which was much higher than that of Fe/SBA-15 (about $240 \mathrm{Oe}$ ). Meanwhile, $\mathrm{Co}_{3} \mathrm{O}_{4}$ was antiferromagnetic with zero net magnetic moment. As a result, Ms decreased for higher density $8 \% \mathrm{Fe} / \mathrm{SBA}-15-\mathrm{Co}_{3} \mathrm{O}_{4}$ due to the addition of

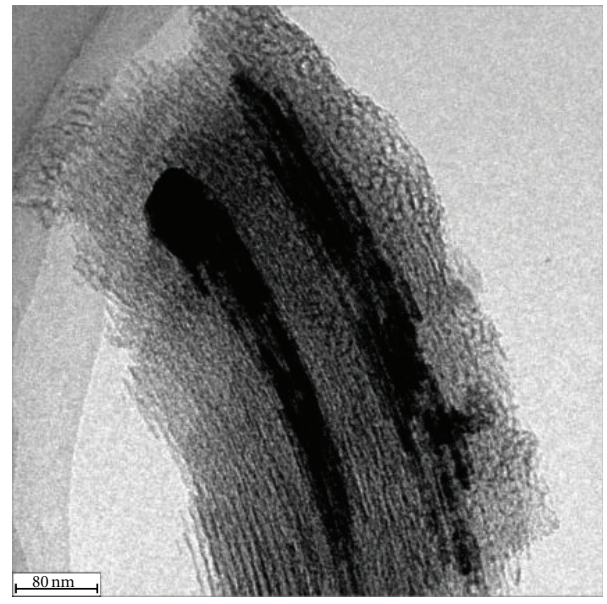

(a)

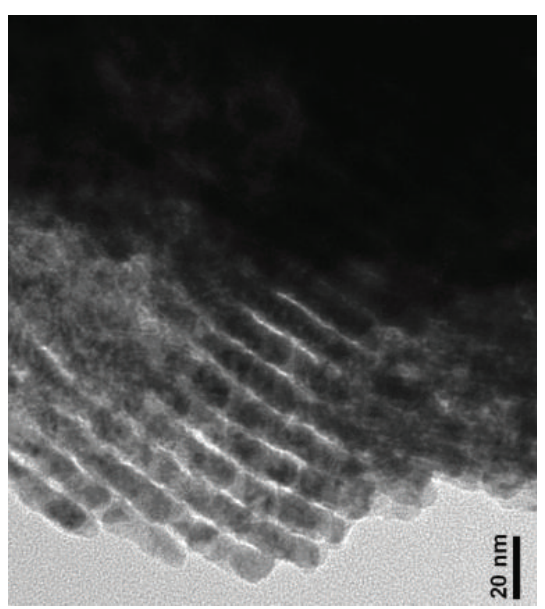

(b)

Figure 7: TEM images of nanocomposite $8 \% \mathrm{Fe} / \mathrm{SBA}-15-\mathrm{Co}-0.02$ (a) and $\mathrm{Co}_{3} \mathrm{O}_{4}$ nanowires (b).

$\mathrm{Co}_{3} \mathrm{O}_{4}$ nanoparticles. Thus, Ms decreased from $0.7 \mathrm{emu} \cdot \mathrm{g}^{-1}$ for $8 \% \mathrm{Fe} / \mathrm{SBA}-15$ to $0.3 \mathrm{emu} \cdot \mathrm{g}^{-1}$ for $8 \% \mathrm{Fe} / \mathrm{SBA}-15-\mathrm{Co}-$ 0.02. Compared with our previous work [28], through introducing the different magnetic nanoparticles to SBA-15, the magnetic parameters of SBA-15 nanocomposites could be controlled to a certain extent for potential applications in magnetic drug targeting.

\section{Conclusion}

Mesoporous Fe/SBA-15 materials were prepared by sol-gel and hydrothermal processes, and $\mathrm{Co}_{3} \mathrm{O}_{4}$ nanoparticles were implanted into the mesopores of Fe/SBA-15 through impregnation. XRD, HRTEM, and $\mathrm{N}_{2}$ physisorption isotherms results indicated that the synthesis of $\mathrm{Fe}_{2} \mathrm{O}_{3}$ loaded SBA-15 caused no damage to the microstructure of SBA-15, while the $\mathrm{Co}_{3} \mathrm{O}_{4}$ nanoparticles exist in the mesopores of Fe/SBA15. Because $\alpha-\mathrm{Fe}_{2} \mathrm{O}_{3}$ is spin antiferromagnetic, Fe/SBA-15 exhibits ferromagnetism with low Ms from $0.6 \mathrm{emu} \cdot \mathrm{g}^{-1}$ for $4 \% \mathrm{Fe} / \mathrm{SBA}-15$ to $0.85 \mathrm{emu} \cdot \mathrm{g}^{-1}$ for $16 \% \mathrm{Fe} / \mathrm{SBA}-15$. With the 


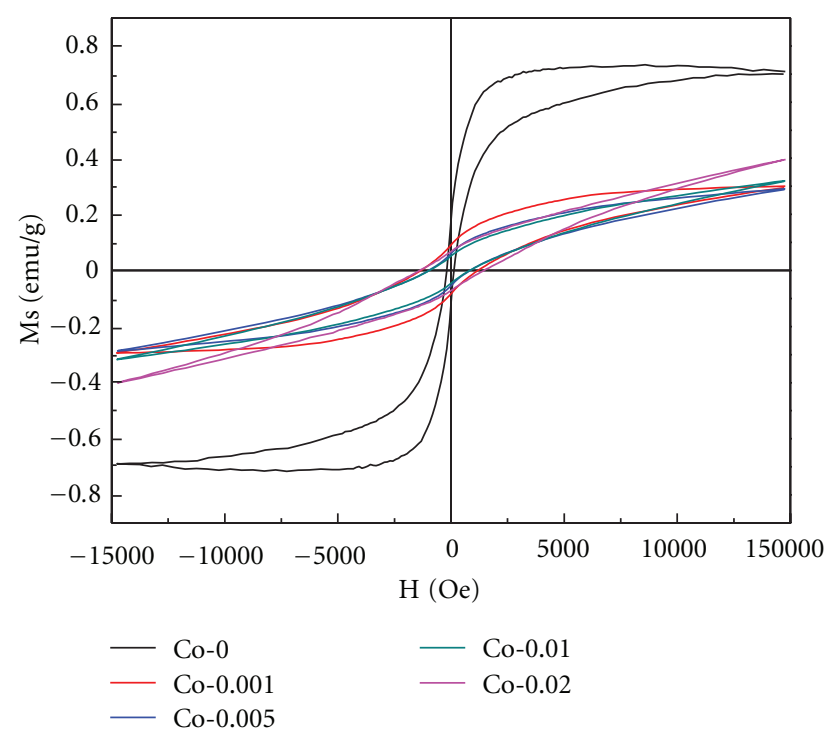

Figure 8: Hysteresis loops of $8 \% \mathrm{Fe} / \mathrm{SBA}-15-\mathrm{Co}_{3} \mathrm{O}_{4}$ nanocomposites.

introduction of antiferromagnetic $\mathrm{Co}_{3} \mathrm{O}_{4}$ nanoparticles, $\mathrm{Hc}$ of $\mathrm{Fe} / \mathrm{SBA}-15-\mathrm{Co}_{3} \mathrm{O}_{4}$ was affected greatly and increases from 200 Oe for Fe/SBA-15 to 1424.6 Oe for Fe/SBA-15-Co-0.02, while Ms decreased slightly due to the higher density for the additional $\mathrm{Co}_{3} \mathrm{O}_{4}$. Such impregnation method enabled us to easily improve Ms and $\mathrm{Hc}$ and enhance the magnetic response, which promised great potentials in application such as magnetic drug targeting.

\section{Acknowledgments}

The research was funded by the National Natural Science Foundation of China (nos. 21001098, 51172220, and 51172219), Zhejiang Province Science Foundation (no. Z4090462), and Innovation Team Foundation of Science and Technology Department of Zhejiang Province (no. 2010R50016).

\section{References}

[1] D. Zhao, J. Feng, Q. Huo et al., "Triblock copolymer syntheses of mesoporous silica with periodic 50 to 300 angstrom pores," Science, vol. 279, no. 5350, pp. 548-552, 1998.

[2] R. Ryoo, C. H. Ko, M. Kruk, V. Antochshuk, and M. Jaroniec, "Block-copolymer-templated ordered mesoporous silica: array of uniform mesopores or mesopore-micropore network?" Journal of Physical Chemistry B, vol. 104, no. 48, pp. 11465-11471, 2000.

[3] H. J. Shin, C. H. Ko, and R. Ryoo, "Synthesis of platinum networks with nanoscopicperiodicity using mesoporous silica as template," Journal of Materials Chemistry, vol. 11, pp. 260-261, 2001.

[4] A. Taguchi and F. Schüth, "Ordered mesoporous materials in catalysis," Microporous and Mesoporous Materials, vol. 77, no. 1, pp. 1-45, 2005.

[5] L. L. Kong, B. Yan, and Y. Li, "Hybrid materials of SBA-15 functionalized by $\mathrm{Tb}^{3+}$ complexes of modified acetylacetone: covalently bonded assembly and photoluminescence," Journal of Alloys and Compounds, vol. 481, pp. 549-554, 2009.

[6] L. Zhang, S. Z. Qiao, Y. G. Jin et al., "Fabrication and sizeselective bioseparation of magnetic silica nanospheres with highly ordered periodic mesostructure," Advanced Functional Materials, vol. 18, pp. 3203-3212, 2008.

[7] S. S. Huang, P. P. Yang, Z. Y. Cheng et al., "Synthesis and characterization of magnetic $\mathrm{Fe}_{x} \mathrm{O}_{y}$ SBA-15 composites with different morphologies for controlled drug release and targeting," Journal of Physical Chemistry, vol. 112, no. 18, pp. 71307137, 2008.

[8] H. Li, J. Li, H. Ni, and D. Chen, "Studies on cobalt catalyst supported on silica with different pore size for Fischer-Tropsch synthesis," Catalysis Letters, vol. 110, pp. 71-76, 2006.

[9] Y. Park, T. Kang, P. Kim et al., "Encapsulation method for the dispersion of $\mathrm{NiO}$ onto ordered mesoporous silica, SBA15, using polyethylene oxide (PEO)," Journal of Colloid and Interface Science, vol. 295, pp. 464-471, 2006.

[10] Y. Zhu, S. Kaskel, T. Ikoma, and N. Hanagata, "Magnetic SBA-15/poly(N-isopropylacrylamide) composite: preparation, characterization and temperature-responsive drug release property," Microporous and Mesoporous Materials, vol. 123, no. 1-3, pp. 107-112, 2009.

[11] Z. Luan, J. Y. Bae, and L. Kevan, "Vanadosilicate mesoporous SBA-15 molecular sieves incorporated with N-alkylphenothiazines," Chemistry of Materials, vol. 12, no. 10, pp. 3202-3207, 2000.

[12] F. Schüth, A. Wingen, and J. Sauer, "Oxide loaded ordered mesoporous oxides for catalytic applications," Microporous and Mesoporous Materials, vol. 44-45, pp. 465-476, 2001.

[13] W. Hua, Y. Yue, and Z. Gao, "Acidity enhancement of SBA mesoporous molecular sieve by modification with $\mathrm{S}_{4}^{2-} / \mathrm{ZrO}_{2}$," Journal of Molecular Catalysis A, vol. 170, pp. 195-202, 2001.

[14] K. Zhu, Z. Ma, Y. Zou et al., "Mesoporous $\mathrm{VO}_{x}-\mathrm{SbO}_{x} / \mathrm{SBA}-15$ synthesized by a two-stage grafting method and its characterization," Chemical Communications, pp. 2552-2553, 2001.

[15] Y. Li, W. Zhang, L. Zhang et al., "Direct synthesis of Al-SBA15 mesoporous materials via hydrolysis-controlled approach," Journal of Physical Chemistry B, vol. 108, no. 28, pp. 97399744, 2004.

[16] J. S. Jung, K. H. Choi, Y. K. Jung et al., "Preparation and characterization of $\gamma$ - $\mathrm{Fe}_{2} \mathrm{O}_{3}$ nanoparticles in SBA15 host material," Journal of Magnetism and Magnetic Materials, vol. 272-276, supplement, pp. E1157-E1159, 2004.

[17] Y. Du, S. Liu, Y. Ji et al., "Ordered mesoporous silica materials (SBA-15) with good heat-resistant magnetism," Journal of Magnetism and Magnetic Materials, vol. 320, pp. 1932-1936, 2008.

[18] C. M. Yang, H. A. Lin, B. Zibrowius et al., "Selective surface functionalization and metal deposition in the micropores of mesoporous silica SBA-15," Chemistry of Materials, vol. 19, no. 13, pp. 3205-3211, 2007.

[19] Z. Lei, S. Bai, L. Dang et al., " $\mathrm{Fe}_{2} \mathrm{O}_{3} / \mathrm{SBA}-15$ catalyst synthesized by chemical vapor infiltration for Friedel-Crafts alkylation reaction," Microporous and Mesoporous Materials, vol. 123, no. 1-3, pp. 306-313, 2009.

[20] H. H. P. Yiu, M. A. Keane, Z. A. D. Lethbridge, M. R. Lees, A. J. El Haj, and J. Dobson, "Synthesis of novel magnetic iron metal-silica (Fe-SBA-15) and magnetite-silica $\left(\mathrm{Fe}_{3} \mathrm{O}_{4}\right.$ SBA-15) nanocomposites with a high iron content using temperature-programed reduction," Nanotechnology, vol. 19, no. 25, Article ID 255606, 2008. 
[21] W. Zhao, J. Gu, L. Zhang et al., "Fabrication of uniform magnetic nanocomposite spheres with a magnetic core/mesoporous silica shell structure," Journal of the American Chemical Society, vol. 127, no. 25, pp. 8916-8917, 2005.

[22] H. Lin, C. Liu, W. Huang S et al., "Novel magnetically separable mesoporous $\mathrm{Fe}_{2} \mathrm{O}_{3}$ SBA-15 nanocomposite with fully open mesochannels for protein immobilization," Chemistry of Materials, vol. 20, no. 21, pp. 6617-6622, 2008.

[23] Q. Yang, S. Wang, P. Fan et al., "pH-responsive carrier system based on carboxylic acid modified mesoporous silica and polyelectrolyte for drug delivery," Chemistry of Materials, vol. 17, no. 24, pp. 5999-6003, 2005.

[24] A. Dyal, K. Loos, M. Noto et al., "Activity of Candida rugosa lipase immobilized on $\gamma$ - $\mathrm{Fe}_{2} \mathrm{O}_{3}$ magnetic nanoparticles," Journal of the American Chemical Society, vol. 125, no. 7, pp. 1684 $1685,2003$.

[25] H. H. P. Yiu and P. A. Wright, "Enzymes supported on ordered mesoporous solids: a special case of an inorganic-organic hybrid," Journal of Materials Chemistry, vol. 15, pp. 369033700, 2005.

[26] X. Q. Wang, H. L. Ge, H. X. Jin, and Y. J. Cui, "Influence of Fe on the thermal stability and catalysis of SBA-15 mesoporous molecular sieves," Microporous and Mesoporous Materials, vol. 86, no. 1-3, pp. 335-340, 2005.

[27] H. Jin, L. Li, N. Chu et al., "Magnetic properties of nanocomposite Fe-doped SBA-15 magnetic materials," Materials Chemistry and Physics, vol. 112, pp. 112-114, 2008.

[28] X. Wang, M. Chen, L. Li et al., "Magnetic properties of SBA15 mesoporous nanocomposites with $\mathrm{CoFe}_{2} \mathrm{O}_{4}$ nanoparticles," Materials Letters, vol. 64, pp. 708-710, 2010.

[29] A. Martinez, C. Lopez, and F. Marquez, "Fischer-Tropsch synthesis of hydrocarbons over mesoporous Co/SBA- 15 catalysts: the influence of metal loading, cobalt precursor, and promoters," Journal of Catalysis, vol. 220, pp. 486-499, 2003.

[30] A. Y. Khodakov, A. Griboval-Constant, R. Bechara, and V. L. Zholobenko, "Pore size effects in Fischer Tropsch synthesis over cobalt-supported mesoporous silicas," Journal of Catalysis, vol. 206, no. 2, pp. 230-241, 2002.

[31] A. Y. Khodakov, R. Bechara, and A. Griboval-Constant, "Fischer-Tropsch synthesis over silica supported cobalt catalysts: mesoporous structure versus cobalt surface density," Applied Catalysis A, vol. 254, no. 2, pp. 273-288, 2003. 

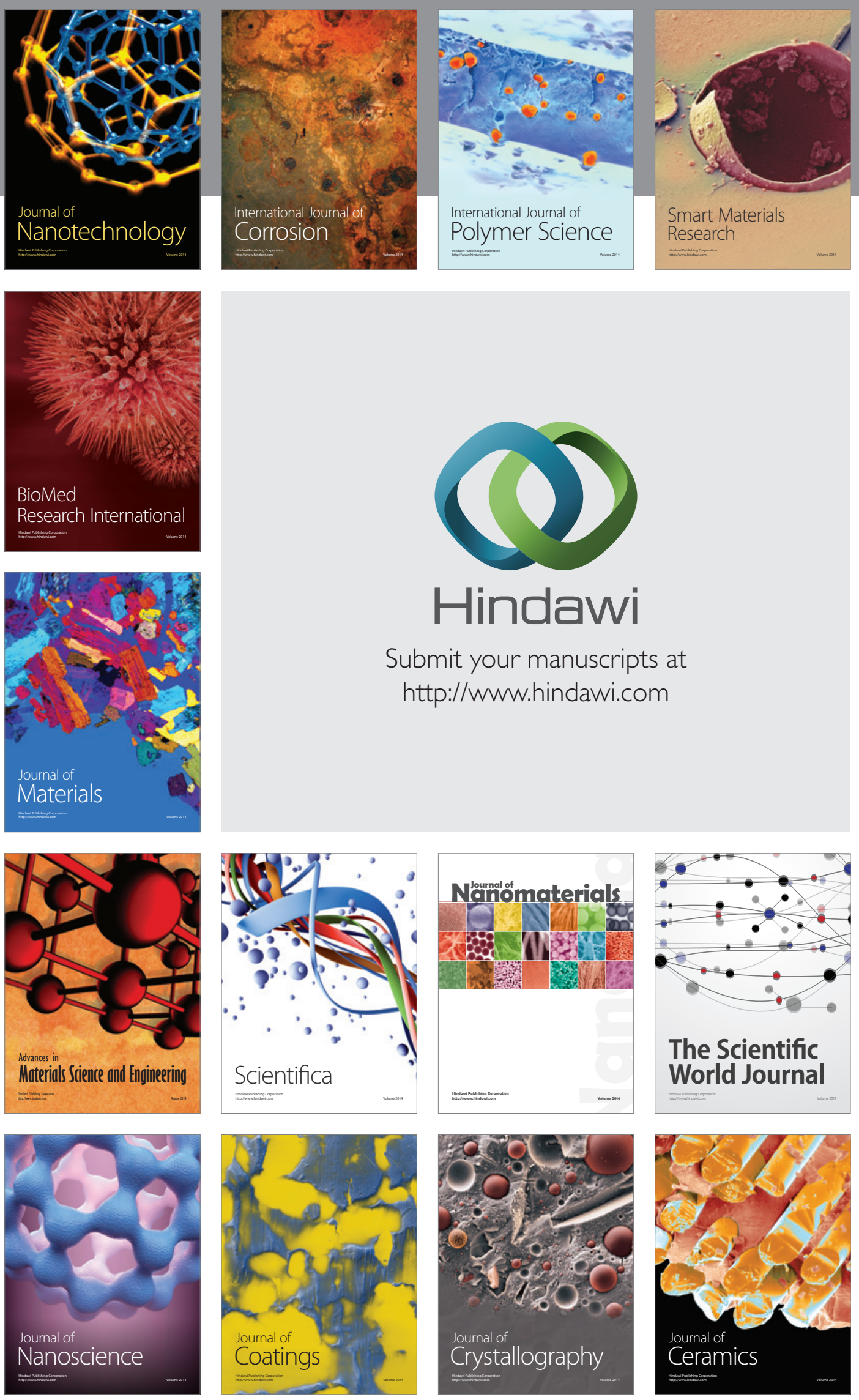

The Scientific World Journal

Submit your manuscripts at

http://www.hindawi.com

\section{World Journal}

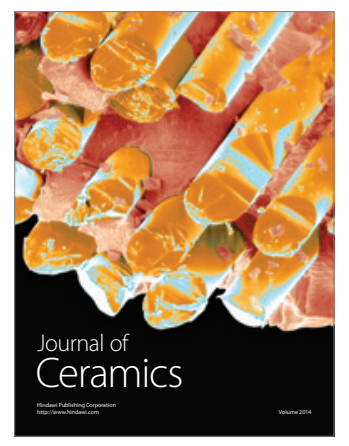

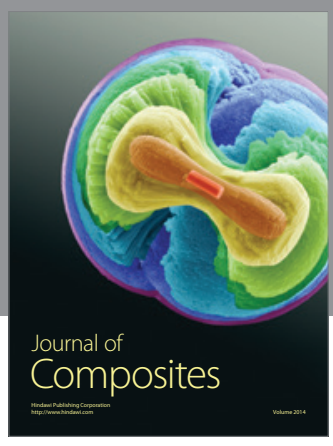
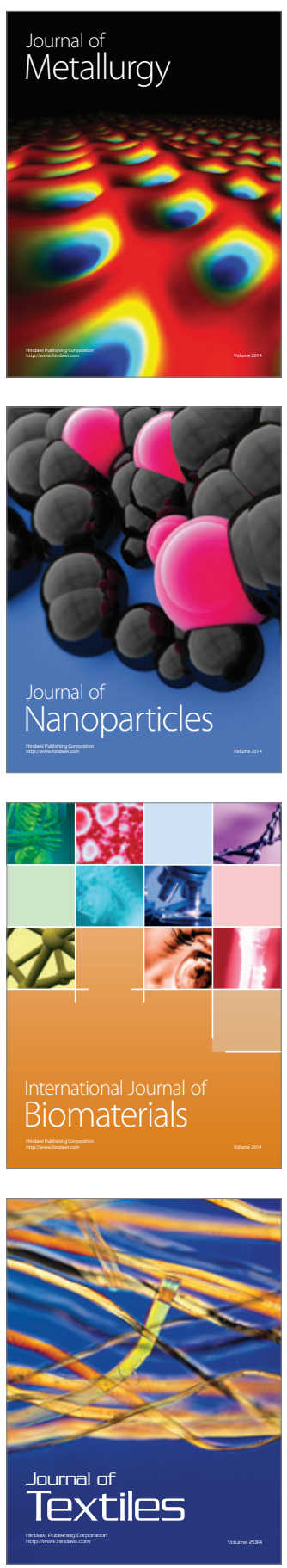